\title{
COLOR VARIATION IN WESTERN RED LILY
}

BRIAN IRVING, Box 727, Kelvington, Saskatchewan. SOA 1W0

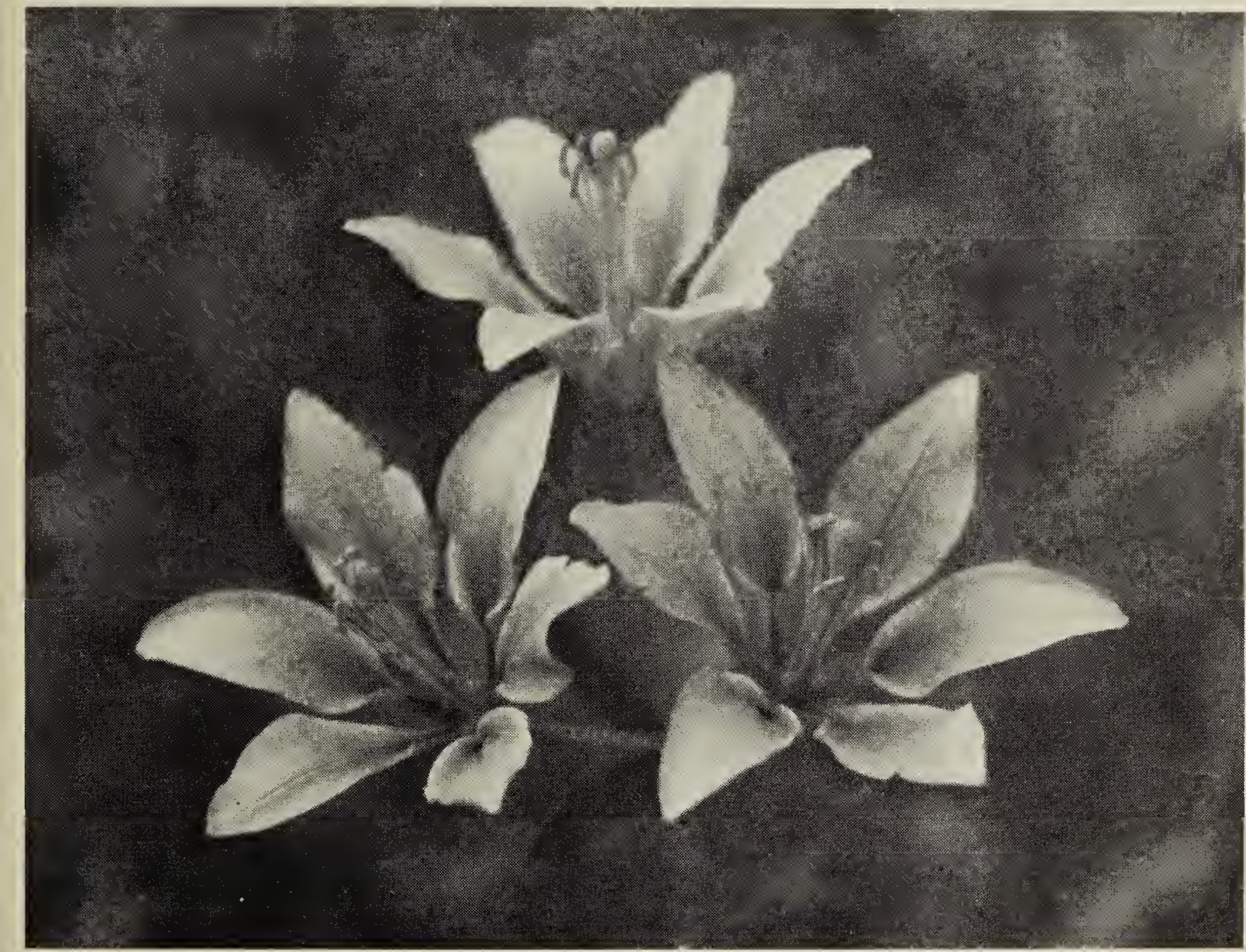

Yellow-flowered Western Red Lily.

Brian Irving

During the summer of 1982, there were unusually abundant and brilliant displays of our floral emblem, the Western Red Lily (Lilium philadelphicum var. andinum), in the parklands of Saskatchewan.

An exciting discovery for me was to find yellow flowered lilies at two sites on our farm. We often see lilies with flowers of various shades of red, pink, or orange, but these were definitely yellow. The habitat at both sites was native, slightly saline meadow which has a history of being good lily country.
The first plant was discovered 4 July 1982. At that time it had two open flowers and one bud which later opened. These flowers were entirely yellow without the dark spots which are typical of the Western Red Lily. Even the pollen was yellow.

Shortly after this find, a second location was discovered about a mile from the first, which eventually produced six yellow-flowering plants within a radius of about fifteen metres. This site was visited by Jim and Shirley Jowsey on 15 July 1982. 


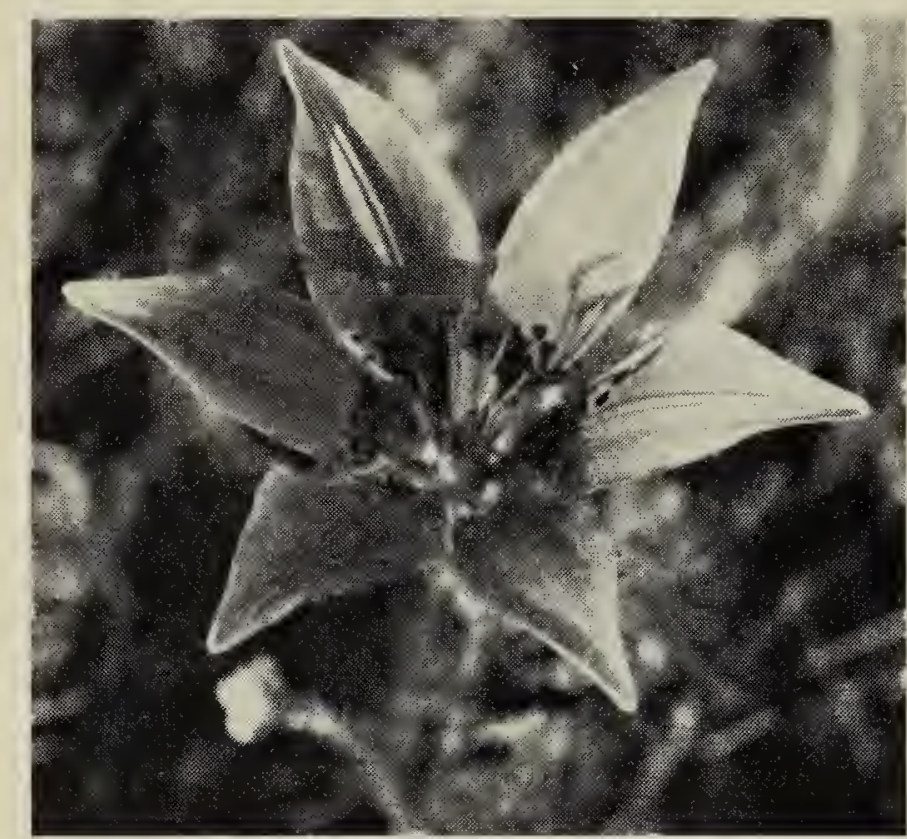

Yellow-flowered lily
Brian Irving

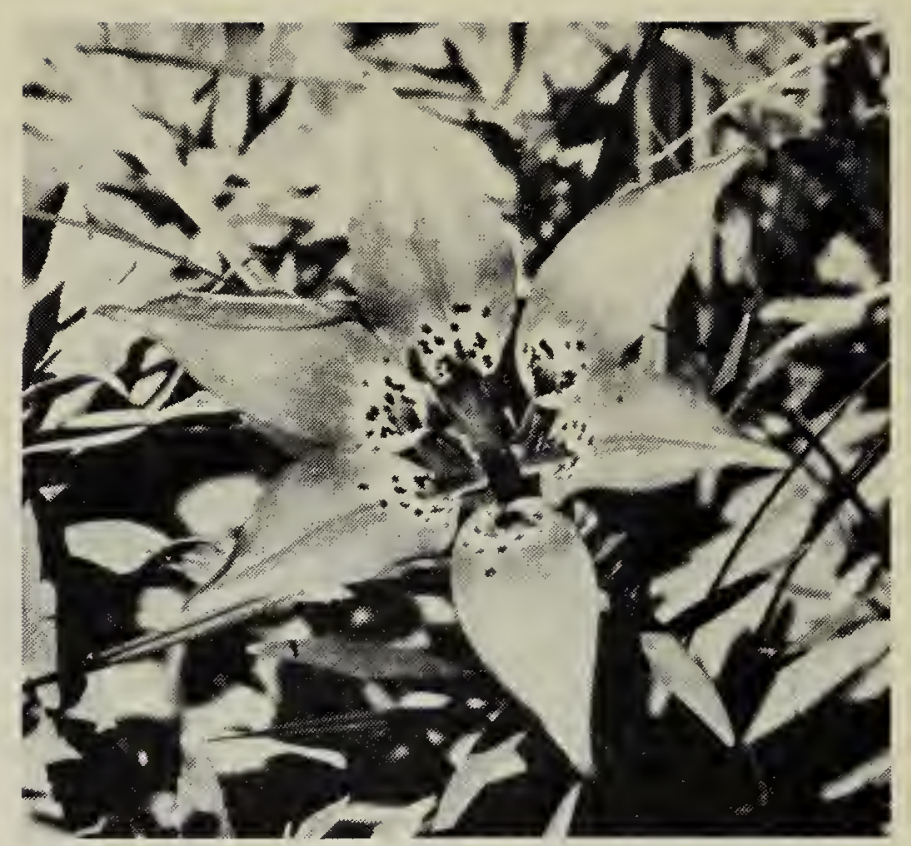

Normal colored Western Red Lily.

J. B. Gollop
The plants here exhibited considerable variation in color pattern. Two plants each produced a single yellow flower with faint, greyish spots. One plant had a single orangish-yellow flower with red spots, and brown anthers and stigma. Two more plants each had two flowers, all yellow with no spotting. The other lily produced a single deep yellow flower with brown anthers and stigma.

There were some characteristics which these yellow-flowered plants had in common. They appeared more vigorous and were 5 to $10 \mathrm{~cm}$ taller, with thicker stems, than the red flowered plants growing next to them. The foliage was extremely smooth and a pale green, while the ribs of the stem, usually brownish, were a dark shade of green. The entire plants exhibited atypical coloration.

According to Scoggan yellowflowering lilies have been identified as Lilium philadelphicum L. var. andinum (Nutt) Ker. forma immaculata Raup. ${ }^{2} \mathrm{He}$ describes them as "flowers lemonyellow, devoid of the usual dark spots; (known from the type locality, Jenkins Lake, Alberta)". Boivin also mentions forma immaculata as having "flowers yellow and spotless or the spots rather weak" and he indicates specimens have been found in Manitoba, Saskatchewan, and Alberta.' Scoggan also mentions a yellow form of the eastern variety Lilium philadelphicum L. var. philadelphicum forma flaviforum Williams. He indicates this form was observed near Moosehorn, Manitoba. ${ }^{2}$

It seems that these yellow color variations do occur periodically but certainly not frequently nor are they widespread. It would be most interesting if anyone having observed these yellow lilies in natural habitat would report their sightings to the Blue Jay or to myself.

\section{Acknowledgements}

I would like to thank Jim and Shirley Jowsey for coming to verify my siting and for their support in the preparation of this article. I also want to thank J. H. Hudson for his personal correspondence and for referring me to the texts mentioned.

BOIVIN, BERNARD 1967, Flora of the Prairie Provinces, Part IV, Herbier Louis-Marie, Universite Laval and Department of Agriculture, Ottawa.

2 SCOGGAN, H.J. 1978, The Flora of Canada, Part Two, National Museums of Canada, Ottawa. 